\title{
PREVALENCE OF ANISAKID NEMATODE LARVAE INFECTING SOME MARINE FISHES FROM THE LIBYAN COAST
}

\section{By}

HAMED H. KASSEM ${ }^{1 *}$ AND SALEM MOHAMED BOWASHI ${ }^{2}$

Departments of Zoology, Faculties of Science, Benghazi University ${ }^{1 *}$ and Omar Al-mukhtar University ${ }^{2}$, Libya ( ${ }^{*}$ Correspondence .e-mail: Hamedkass@yahoo.com)

\begin{abstract}
This study examined eight hundred ninety six marine fishes belonging to nine different fish species; Synodus saurus; Merluccius merluccius; Trachurus mediterraneus; Serranus cabrilla; Mullus surmuletus; Diplodus annularis; Spicara maena; Siganus rirulatus and Liza rama$d a$. The fishes were bought from fish markets at five different sites on Libyan coast, from January to December 2013, for study the anisakids larvae among them. The results showed that 344/896 fishes (38.4\%) were infected with Anisakids larvae. S. saurus was the highly infected (80.9\%), followed by T. mediterraneus $(77.5 \%)$ but, S. cabrilla, S. maena, M. merluccius, M. surmuletus, and D. annularis were least anisakid infected showed rates of $58.2 \%$, $53.8 \%, 43.7 \%, 36.7 \% \& 3.6 \%$, respectively. No parasites were in $S$. rirulatus and $L$, ramada. Ten species of Anisakids larvae was detected during the present study. Two Pseudoterranova sp. Larvae, two types of Anisakis larvae, Anisakis simplex larva and Anisakis sp. Larva, two types of Contracaecum sp. Larvae and four Hysterothylacium larvae. Females showed higher prevalence than males. The number of anisakid larvae varied according to body length and weight of infected fish, without significant difference between prevalence and seasons, but, a significant difference was between prevalence and regions.
\end{abstract}

Key words: Libya, Nine Mediterranean Fish, Anisakids larvae

\section{Introduction}

Fishes have substantial social and economic importance as they act as a vital source of food for people. They are considered as a single source of high-quality protein, providing $\simeq 16 \%$ of the animal protein consumed by the world's population. Fishes are also zoonotic important, since several diseases transmitted to human by fish parasites including Anisakiasis, in additions hundreds of fishes suffer due to infection by helminthes parasites, several species of fish parasites have been identified as harmful (Bilqees et al, 2003).

Marine fish are known to be infected by many different parasites. Some nematodes are endoparasites in marine mammals, sea birds and fish, there are four main Anisakids known to infect marine fish: Anisakis, Pseudoterranova, Contracaecum and Hysterothylacium (Berland, 2006). Anisakids spp. larvae are a worldwide distribution parasite commonly found in the flesh and the body cavity of many species of marine fishes as well as cephalopods that act as paratenic or transport hosts (Tantanasi, et al, 2012). Anisakids are ascaridoid nematodes dependent upon aquatic hosts for the completion of their life cycle, which generally involves an array of invertebrates and fish as intermediate or paratenic hosts, and marine mammals or fish-eating birds, reptiles and fishes as definitive hosts (Koinari et al, 2013). Larvae of Anisakid nematodes are a major problem for commercial fishing industries, and are potential human health hazards, both as causative agents of anisakiasis and as potential food-borne allergens (Daschner and Pascual, 2005).

Human Anisakiasis is seafood borne parasitic zoonosis caused by larval nematodes of the genus Anisakis (Arafa et al, 2009). Humans are accidental hosts of the nematodes; they become infected by consuming raw or undercooked seafood that harbor the nematode larvae in their flesh and muscle. Larvae do not further develop in humans; however, they can penetrate the gastrointestinal tract and form eosinophilic granulomas, often with pathologic consequences (Audicana and Kennedy, 2008). 
The present study report on the occurrence and infection of Anisakid larvae in some commercial fish species in Libya, these fish species under study are routinely used in the diet of the local population.

\section{Materials and Methods}

Study area (The Libyan coast): The Libyan state has a vast coast line of $1970 \mathrm{Kms}$. of the Mediterranean Sea. The Libyan coast extending from Ras Jadir on the LibyanTunisian border to the Libya-Egyptian border.The Libyan coast has a Mediterranean climate of the moderate wet winter and worm, dry summer. During the winter season the temperature may drop to less than $5^{\circ} \mathrm{C}$ at night but the average temperature between $10-17^{\circ} \mathrm{C}$, whereas the temperature was raised up to $38^{\circ} \mathrm{C}$ at the mid-day during the summer season. Annual rainfall was $268 \mathrm{~mm}$.

Fish sampling: A total of eight hundred and ninety six of marine fishes belong to nine genera were collected from the Libyan coast with the help of fisherman and bought from fish markets at different cities, collected fishes were transferred in icebox to the laboratory of zoology department, Faculty of Science, Omar Al-mukhtar University, Libya from January to December 2013. Collected fishes were first identified by the experience of fisherman with their local common names. Scientific identification was done according to Golani et al. (2006). All fish species belonged to Class: Osteischthyes, Families and genera to which the different species belong to following species: Trachurus mediterraneus (80); Merluccius merluccius (87); Synodus saurus (110); Serranus cabrilla (110); Mullus surmuletus (120); Diplodus annularis (110); Spicara maena (80) Siganus rirulatus (110) and Liza ramada (89).

Laboratory examination of fish for parasites: Total body length was measured by meter and body weight was measured by gram using an electronic balance. Fish sexes was determined on dissection.
Parasite diagnosis: Fishes were dissected. The whole body cavity, muscles, internal organs and gonads of each sample were carefully examined at first by naked eye for the presence of Anisakids larvae .Collected larvae were washed with in isotonic saline solution for several times to remove any attached mucous. Anisakid larvae presserved in 5\% glycerin in $70 \%$ ethanol to straighten up the nematodes body during fixation and for preventing the dryness of the larvae and kept in small plastic tubes with a label carrying the most important information. The anisakid larvae were carefully washed in distilled water. They were cleared by gradual evaporation of glycerin alcohol for several days, cleared in glycerin and permanently mounted in glycerin. Then left to dry on hot plate at $30-50^{\circ} \mathrm{C}$ for 30 minutes, and examined microscopically.

Identification of Anisakids larvae: Anisakids larvae were identified based on the morphological characters (Moravec, 1994 and Choi et al., 2011), and based on the assistance of Prof. Dr. Ali Al-Zubaidy, Department of Marine Biology \& Fisheries, Faculty of Marine Science and Environment, Hodeidah University, Yemen.

Statistical Analysis: Data were analyzed using SPSS version-17 software. Pearson's Chi square test has been used to measure statistical significance of results. In order to consider a result to be statistically significant $95 \% \mathrm{CI}$ and $p$-value $<0.05$ has been taken.

\section{Results}

The results showed that out of the total examined fish, 344 (38.4\%) were infected with L3 Anisakids larvae parasites. Morphological examination revealed that all larvae specimens examined belonged to the family Anisakidae. Larvae were found free in the body cavity and encapsulated (coiled in a thin walled cyst) on wall of stomach, liver, and muscles (Tab. 1). 
Table 1: Overall prevalence of larval anisakid parasites in fishes:

\begin{tabular}{|l|c|c|}
\hline Status & No. infected & Percentage (\%) \\
\hline Non- infected & 552 & 61.6 \\
\hline Infected & 344 & 38.4 \\
\hline Total & 896 & 100.0 \\
\hline
\end{tabular}

Synodus saurus was commonest $(80.9 \%)$, followed by $T$. mediterraneus $(77.5 \%)$. While, S. cabrilla, S. maena, M. merluccius, M. surmuletus and D. annularis showed infection rates of $58.2 \%, 53.8 \%$,
$43.7 \%, 36.7 \% \& 3.6 \%$, respectively. None was detected in $S$. rirulatus and $L$ ramada. There was a significant difference between prevalence and fish species $(\mathrm{P}=0.000)$.

Table 2: Prevalence of larval anisakid parasites in fish species:

\begin{tabular}{|l|c|c|c|}
\hline Fish species & No. examined & Non-infected & Infected \\
\hline Trachurus mediterraneus & 80 & $22.5 \%(18)$ & $77.5 \%(62)$ \\
\hline Merluccius merluccius & 87 & $56.3 \%(49)$ & $43.7 \%(38)$ \\
\hline Synodus saurus & 110 & $19.1 \%(21)$ & $80.9 \%(89)$ \\
\hline Serranus cabrilla & 110 & $41.8 \%(46)$ & $58.2 \%(64)$ \\
\hline Mullus surmuletus & 120 & $63.3 \%(76)$ & $36.7 \%(44)$ \\
\hline Diplodus annularis & 110 & $96.4 \%(106)$ & $3.6 \%(4)$ \\
\hline Spicara maena & 80 & $46.2 \%(37)$ & $53.8 \%(43)$ \\
\hline Siganus rirulatus & 110 & $100 \%(110)$ & $0.00(0)$ \\
\hline Liza ramada & 89 & $100 \%(89)$ & $0.00(0)$ \\
\hline Total & 896 & 552 & 344 \\
\hline
\end{tabular}

Table 3: Prevalence of larval anisakid parasites in examined fishes and sexes:

\begin{tabular}{|c|c|c|c|}
\hline Sex & No. examined & Non-infected & Infected \\
\hline Males & 180 & $65 \%(117)$ & $35 \%(63)$ \\
\hline Females & 716 & $60.8 \%(435)$ & $39.2 \%(281)$ \\
\hline Total & 896 & 552 & 344 \\
\hline
\end{tabular}

Anisakid larvae were $22.1 \%, 37.9 \%$, with length $13-18.5 \mathrm{~cm}$ and $19-24.5 \mathrm{~cm}$ $67.3 \%, 24.1 \% \& 16.7 \%$ at body lengths 7 $12.5 \mathrm{~cm}, 13-18.5 \mathrm{~cm}, 19-24.5 \mathrm{~cm}, 25-30.5 \mathrm{~cm}$ and more than $30.5 \mathrm{~cm}$ respectively. Fishes showed higher prevalence. There was a significant difference between prevalence and body length $(\mathrm{P}=0.000)$.

Table 4: Prevalence of larval anisakid parasites and body length of examined fishes :

\begin{tabular}{|c|c|c|c|}
\hline Body length $(\mathrm{cm})$ & No. examined & Non-infected & Infected \\
\hline $7-12.5$ & 235 & $77.9 \%(183)$ & $22.1 \%(52)$ \\
\hline $13-18.5$ & 430 & $62.1 \%(267)$ & $37.9 \%(163)$ \\
\hline $19-24.5$ & 171 & $32.7 \%(56)$ & $67.3 \%(115)$ \\
\hline $25-30.5$ & 54 & $75.9 \%(41)$ & $24.1 \%(13)$ \\
\hline 30.5 More than & 6 & $83.3 \%(5)$ & $16.7 \%(1)$ \\
\hline Total & 896 & 552 & 344 \\
\hline
\end{tabular}

Prevalence of anisakid larvae parasites varied according to fish body weight. High infection rate was with body weight 115 $165 \mathrm{gm} 57 \%$ (73) followed by body weights 166-216gm 43.5\% (20), 64-114gm 42.2\% (116), 13-63gm 32.6\% (125) and 217267gm 20.7\% (6), 268-318gm 15\% (3), $319-369 \mathrm{gm} 12.5 \%$ (1), 370-420gm $0.00 \%$ $(0)$, and more than $420 \mathrm{gm} 0.00 \%(0)$, with significant difference between infection rate and fish body weight $(\mathrm{P}=0.000)$.
High infection rate was in Spring (45.2\%) followed by Autumn (37.7\%), Winter (34.2\%) and Summer (34\%), but without significant difference between infection rate and seasons $(\mathrm{P}=0.390)$. Infection rate in Tripoli was $(46.1 \%)$, in Benghazi (39.7\%), and in Darna (21.7\%) but none in Ras-Altten or Al-Tememi $(0.0 \%)$, with a significant difference between infection rate and regions $(\mathrm{P}=0.000)$. 
Table 5: Prevalence of larval anisakid parasites and body weight of fishes.

\begin{tabular}{|l|c|c|c|}
\hline Body weight $(\mathrm{g})$ & No. of examined fish & Non-infected & Infected \\
\hline $63-13$ & 383 & $67.4 \%(258)$ & $32.6 \%(125)$ \\
\hline $114-64$ & 275 & $57.8 \%(159)$ & $42.2 \%(116)$ \\
\hline $165-115$ & 128 & $43 \%(55)$ & $57 \%(73)$ \\
\hline $166-216$ & 46 & $56.5 \%(26)$ & $43.5 \%(20)$ \\
\hline $217-267$ & 29 & $79.3 \%(23)$ & $20.7 \%(6)$ \\
\hline $268-318$ & 20 & $85 \%(17)$ & $15 \%(3)$ \\
\hline $319-369$ & 8 & $78.5 \%(7)$ & $12.5 \%(1)$ \\
\hline $370-420$ & 4 & $100 \%(4)$ & $0.00 \%(0)$ \\
\hline More than420 & 3 & $100.0 \%(3)$ & $0.00 \%(0)$ \\
\hline Total & 896 & 552 & 344 \\
\hline
\end{tabular}

Table 6: Prevalence of larval anisakid parasites in fishes and seasons.

\begin{tabular}{|l|c|c|c|}
\hline Seasons & No. examined & Non-infected & Infected \\
\hline Summer & 150 & $66 \%(99)$ & $34 \%(51)$ \\
\hline Autumn & 236 & $62.3 \%(147)$ & $37.7 \%(89)$ \\
\hline Winter & 240 & $65.8 \%(158)$ & $34.2 \%(82)$ \\
\hline Spring & 270 & $54.8 \%(148)$ & $45.2 \%(122)$ \\
\hline Total & 896 & 552 & 344 \\
\hline
\end{tabular}

Table 7: Prevalence of larval anisakid parasites in fishes and regions.

\begin{tabular}{|l|c|c|c|}
\hline Regions & No. examined & Non-infected & Infected \\
\hline Benghazi & 476 & $60.3 \%(287)$ & $39.7 \%(189)$ \\
\hline Tripoli & 280 & $53.9 \%(151)$ & $46.1 \%(129)$ \\
\hline Darna & 120 & $78.3 \%(94)$ & $21.7 \%(26)$ \\
\hline Ras-Altten & 10 & $100 \%(10)$ & $0.00 \%(0)$ \\
\hline Al-Tememi & 10 & $100 \%(10)$ & $0.00 \%(0)$ \\
\hline Total & 896 & 552 & 344 \\
\hline
\end{tabular}

Ten species of Anisakids larvae were collected and identified. They were $A$. simplex and Anisakis sp., two types of Contracaecum spp. larvae, two types of Pseudoterranova spp. larvae \& four Hysterothylacium spp. Anisakids larvae in 896 fishes were Pseudo-terranova sp. larva 1 (23.44\%); followed by Pseudo-terranova sp. larva 2 (18\%); Anisakis simplex larva (12.61\%); Contracaecum sp. larva 1 (12.3\%); Hysterothylacium sp. larva 3 (10.16\%); Anisakis sp. larva (8.93\%); Hysterothylacium sp. larva $(8.26 \%)$; Contracaecum sp. larva 2
(3.91\%); Hysterothylacium sp. larva 2 (2.9\%) and Hysterothylacium sp. Larva 4 $(2.68 \%)$. Commonest anisakids larvae in 344 infected fishes was Pseudoterranova sp. larva 1(61.10\%) followed by Pseudoterranova sp. 2 (46.80\%); Anisakis simplex Larva (32.85\%); Contracaecum sp. larva 1 (32\%); Hysterothylacium sp. larva 3 (26.45\%); Anisakis sp. larva (23.26\%); \& Hysterothylacium sp. larva 1 (21.51\%); Contracaecum sp. larva 2(10.17\%); Hysterothylacium sp. larva $2(7.56 \%)$ and Hysterothylacium sp. larva 4 (6.98\%).

Table 8: Prevalence of larval anisakid species parasites in examined $(\mathrm{N}=896)$ and infected fishes $(\mathrm{N}=344)$ :

\begin{tabular}{|c|c|c|}
\hline Parasite & \% Out of fishes (896) & $\%$ Out of infected fishes ( 344) \\
\hline Pseudoterranova sp. larva 1 & $23.44 \%(210)$ & $61.10 \%(210)$ \\
\hline Pseudoterranova sp. larva 2 & $18 \%(161)$ & $46.80 \%(161)$ \\
\hline Contracaecum sp. larva 1 & $12.3 \%(110)$ & $32 \%(110)$ \\
\hline Contracaecum sp. larva 2 & $3.91 \%(35)$ & $10.17 \%(35)$ \\
\hline Anisakis simplex larva & $12.61 \%(113)$ & $32.85 \%(113)$ \\
\hline Anisakis sp. larva & $8.93 \%(80)$ & $23.26 \%(80)$ \\
\hline Hysterothylacium sp. larva 1 & $8.26 \%(74)$ & $21.51 \%(74)$ \\
\hline Hysterothylacium sp. larva 2 & $2.90 \%(26)$ & $7.56 \%(26)$ \\
\hline Hysterothylacium sp. larva 3 & $10.16 \%(91)$ & $26.45 \%(91)$ \\
\hline Hysterothylacium sp. larva 4 & $2.68 \%(24)$ & $6.98 \%(24)$ \\
\hline
\end{tabular}


Single anisakids larvae was $22.97 \%(79)$ and mixed infection was $77.03 \%$ (265), with significant difference between Prevalence and infection type $(\mathrm{P}=0.000)$.

Table 9: Single and mixed infection of anisakid larvae in infected fishes:

\begin{tabular}{|c|c|c|}
\hline Type of infection & No. infected (344) & $\mathbf{( \% )}$ \\
\hline Single infection & 79 & 22.97 \\
\hline Mixed infection & 265 & 77.03 \\
\hline Total & 344 & 100.0 \\
\hline
\end{tabular}

Females were higher than males. Females infection was $39.2 \%$ (281) and males infec-

\section{Discussion}

In the present study the morphological description of anisakid third stage larvae agreed with Shih (2004).In the present investigation, the prevalence of totalexamined nine fish species reached to be $38.4 \%$. This prevalence was higher than those previously reported by other authors, 20\% (Al-Bassel and Hussein, 2012), 16\% (Adel et al, 2013), 5.33\% (Hassan et al, 2013) and 7.6\% (Koinaria et al, 2013). On other hand, the present prevalence was lower than other studies; 97.7\% (Mansour et al, 2003), 75\% (Shamsi et al, 2010), 63.11\% (Khanum et al, 2011) and 65.81\% (Nada et al, 2013). Such variation in data could be due to fish health condition, affected by environmental, geographical distribution, water temperatures, and type of water supply, crowding of fishes, transport, and management (Kayis et al, 2009).

The present study revealed that out of nine examined fish species, seven were infected with Anisakid larvae and two fish species were not, this in agreement with previous studies which reported that not all examined fishes were infected with Anisakid larvae (Shamsi et al, 2010; Hassan et al, 2013; Koinaria et al, 2013).

In the present study, $S$. sauruss showed high rate $(80.9 \%)$, followed by $T$. mediterraneus $(77.5 \%), S$. cabrilla $(58.2 \%), S$. maena (53.8\%), M. merluccius (43.7\%), $M$. surmuletus $(36.7 \%)$ and D. annularis (3.6\%). The same and other fish species were found infected with anisakid larvae recorded around the world (Shamsi and Aghazadeh-Meshgi, 2011; Sobecka et al, 2012). tion was 35\% (63), without significant difference $(\mathrm{P}=0.168)$

The present study revealed that ten species of anisakid larvae belong to four genera were detected among examined nine fish species; they are two Pseudoterranova spp. Larvae, two Contracaecum spp. Larvae, Anisakis simplex Larva, Anisakis sp. Larva and four Hysterothylacium spp. larvae. The same anisakid larvae species were recorded from different fishes around the world (Nada et al, 2011; Shamsi and AghazadehMeshgi, 2011, Sobecka et al, 2012; Adel et al, 2013; Koinaria et al, 2013). The detected prevalence of Anisakis sp. Larva in the present study was $8.93 \%$. Such prevalence was lower than those reported by other previous studies $87.97 \%$ (Valero et al, 2006 a) and 62.4\% (Abattouy et al, 2012) and higher than 2.4\% (Quiazon et al, 2009).

In the present study, two species of Contracaecum larvae were detected at prevalence rates $32 \%$ and $10.17 \%$. This prevalence was higher than those reported in previous studies 3\% (Adel et al, 2013), However lower than incidences reported by Lymbery et al. (2002) at 81-100\%,Valero et al. (2006b) at $87.97 \%$. The differences and similarities of the above results might be attributed to many factors such as the positive correlation of host-parasite interaction, the influence of regional ecological disturbance and the ontogenetically changes in the feeding behavior of fish (Sabas and Luque, 2003).

In the present study mixed infection was high than single infection in all fishes. This agreed with other studies abroad (Khanum et al, 2011; Aliyu and Solomon 2012; Yakhchali et al, 2012). Mixed infections 
had been reported among other helminthes parasitic infection in different fish species (Varjabedian, 2005).

The present finding revealed that females with higher prevalence than the males. The present finding agreed with previous studies (Ahmad and Ahmad, 2012; Olurin et al, 2012) and disagreed with previous studies (Dan-Kishiya et al, 2012, Aliyu and Solomon, 2012; Idris et al, 2013). Such variation in the obtained data could be due to males are known to be usually more sensitive to parasites than females due to testosterone synthesis which may exert a cost, decreasing immune competency (Bichi and Yelwa, 2010). The variation in prevalence between sexes could be due differential feeding or as a result of different levels of resistance to infection. It could be also due to physiological state of the female (Emere and Egbe, 2006).

The results revealed that no significant differences were detected between prevalence of anisakid larvae infection and body length of fishes. This finding agreed with Olurin et al. (2012) but disagreed with others (Khanum et al, 2011; Dan- Kishiya et al, 2012; Yakhchali et al, 2012; Esiest, 2013; Idris et al, 2013).

The relationship between parasites infection and host body length varied according to host and parasite (Hila $\mathrm{Bu}$ and Leong, 1999). This was attributed to variation of fish lengthes, and related to the feeding upon crustacean intermediate hosts or due to an accumulation of parasites in host in its life (Bussmann and Ehrich 1979) or to variations of fish diet (Valero et al, 2006b).

The body weight had effect on the prevalence of anisakid larvae parasites and total infected fishes. This finding agreed with Yakhchali et al, 2012). The prevalence increased with increasing the fish body weight may be due to the increase and growth of the internal organs of the hosts leading to the increase in the surface areas of infection as suggested by Hagras et al. (1995), or could be due to exposure time of infection (Muzzall et al, 1990).

In the present study, the seasonal variations of anisakids larvae infection rate was peaked in spring season in fishes. The result nearly agreed with Eissa (2002) who found that the thin-shelled eggs were laid, and passed out into seawater through the feces of infected final hosts as dolphins or whales (Anisakis), the first stage larva undergoes the first molt within the egg capsule where its development is strongly influenced by water temperature. Thus, water temperature has great role on enhancing the life cycle and increasing prevalence in the summer and spring. These results agreed with Choi et al. (2011) and Li et al. (2011).

Concerning the regions, high prevalence rates were recorded among fishes collected from Tripoli, Benghazi and Darna. But no infection was in fishes from Ras-Altten and Al-Tememi. Many studies gave variations in infection intensity among individual fish within a certain geographic area. Arthur et al. (1982) reported that the infection rate of anisakids larvae varied with geographic location. The infection dynamicwas strongly fish species and area specific (Rokicki et al, 2009). A higher prevalence of Anisakid infection depended on the hosts' availability in the region and the parasite ability to complete life cycle as well as its food and water column inhabited; bottom versus pelagic (Palm et al, 2007).

\section{Conclusion}

In Libya, none was published on the parasites of fish from the Mediterranean Sea. Generally speaking, the anisakiasis is one of the zoonotic parasite, and larvae of Anisakid is a major problem for fishing industries, and in home cooking.

\section{References}

Abattouy, N, Valero, A, Martín-Sánchez, J, Peñalver, MC, Lozano, J, 2012: Sensitization to Anisakis simplex species in the population of Northern Morocco. J. Invest. Allergol. Clin. Immunol. 22, 7:514-9.

Adel, M, Reza, H, Nematolah, A, 2013: Scomberomorus commerson, a new paratenic host of Contracaecum sp. and Anisakis sp. 
(Nematoda: Anisakidae) from Persian Gulf World. J. Fish Marine Sci. 5, 3:310-4.

Ahmad, IKF, Ahmad, T, 2012: Parasitic distribution in relation to gender, season and length of fish hosts in shall Baugh wetland. Kashmir. Int. J. Sci. Engineer. 86:70-7.

Al-Bassel, D, Hussein, A, 2012: A survey on parasites infecting mullets from Egypt and Libya. J. Biol. Sci. 4, 1:9-19.

Aliyu, MD, Solomon, JR, 2012: The intestinal parasite of Clarias gariepinus found at lower us man dam, Abuja. Res. 4, 9:38-44.

Arafa, SZ, Al-Hoot, AA, Hussein, HS, 2009: Pathological and ultrastructural studies on anisakis simplex rudolphi-1809 infecting Carangoides bajad with special reference to intestinal maturation in puppies. J. Egypt. Soc. Parasitol. 39, 2:607-16

Arthur, JR, Margolis, L, Whitaker, DJ, McDonald, TF, 1982: A quantitative study of economically important parasites of walleye Pollock (Theragra chalcogramma) from British Columbian waters and effects of post mortem handling on their abundance in the musculature. J. Fish. Red Bd. Can. 39:710-26.

Audicana, MT, Kennedy, MW, 2008: Anisakis simplex: from obscure infectious worm to inducer of immune hypersensitivity. Clin. Microbiol. Rev. 21:360-7.

Berland, B, 2006: Musings on Nematode Parasites. Fiskenog Havet. Rept. Inst. Mari. Res. 11:1-26.

Bichi, AH, Yelwa, SI, 2010: Incidence of piscine parasites on the gills and gastrointestinal tract of Clarias Garie pinus (Teugels) at Bag auda fish farm, Kano. Bayero. J. Pure Appl. Sci. 3, 1:104-7.

Bilqees, FM, Khatoon, N, Hadi, R, 2003: A new species of the genus Stromaturus, from a fish, Otolithus argenteus of Karachi coast. India. J. Exp. Zool. 8, 2:435-9.

Bussmann, B, Ehrich S, 1979: Investigations on infestation of blue whiting (M-P) with larval Anisakis sp. (Nematoda: Ascaridida) Arch. Fischer Eiwissens Chaf. 29:155-65.

Choi, SH, Jung, K, Jin, Ok, MinKyung, C, et al, 2011: Anisakis simplex larvae; larvae infection status in marine fish and cephalopod purchased from cooperative fish market in Busan, Korea. Korean J. Parasitol. 49, 1:39-44.

Dan-Kishiya, AS, Oboh1, A, Ibrahim, UB, 2012: The prevalence of Helminthes parasites in the gastro-intestinal tract of wild African sharp tooth cat fish Clarias gariepinus (Siluriformes: Clariidae) in Gwagwalada, Nigeria. J. Cuadernos de Invest. Uned. 5, 1:83-87.

Daschner, A, Pascual, CY, 2005: Anisakis simplex: sensitization and clinical allergy. AllerClin. Immunol. 5:281-5.

Emere, MC, Egbe, NEL, 2006: Protozoan parasites of Synodontis Clarias (a fresh water fish) in River Kaduna. Biol. Environ. Sci. J. Tropic. 3, 3:58-64.

Eissa, IAM, 2002: Parasitic fish diseases in Egypt El-Nahda El-Arabia Publisher, 32 Abd El- Khalek Tharwat street, Cairo, Egypt.

Esiest, UL, 2013: Length-weight relationship and parasites of Chrysichthys nigrodigitatus in Cross River Estuary Itulocal government area Akwa Ibom State, Nigeria. J. Agric. Sci. 2, 7: 154-65.

Golani, D, Öztürk, B, Basusta, N, 2006: Fishes of the Eastern Mediterranean, Turkish Marine Research Foundation, Istanbul, Turkey

Hagras, AEM, El-Naggan MM, Mansour. M FA, El-Naggar, AM, 1995: Influence of age, length and sex of the catfish Clarias lazera on infestation with Six Monogenean parasites. Mans. ScL Bull. (Biol). 22, 2:37-55.

Hassan, MA, Mohamed, H, Osman, HM, 2013: Some studies on Anisakidae larvae in some marine fish species. Fish. Res. 5, 12:32.

Hila Bu, S, Leong, TS, 1999: Spatial distribution of Gill Monogeneans in a Tropical Cyprinid from Cenderuh Reservoir, Perak, Malaysia. Malay. Nat. J. 53:239-47.

Idris, HS, Balarabe-Musa, B, Osawe, SO, 2013: The Incidence of endo-parasites of Clarias gariepinus (sharp tooth Catfish) (Burchell, 1822) and Oreochromis niloticus (Tilapia fish) (Linnaeus, 1758) in Jeremiah Usein river, Gwagwalada, Nigeria. Int. J. Biol. Sci. 1, 1:1-5.

Kayis, S, Ozcelep, T, Capkin, E, Altinok, L, 2009: Protozoan and metazoan parasites of cultured fish in Turkey and their applied treatments. J. Aquaculture-Bamidgeh 61, 2:93-102.

Khanum, H, Begum, S, Begum, A, 2011: Season, prevalence, intensity, and original distribution of the helminth, parasites in Macrognathus aculeatus Dhaka Universuty. J. Biol. Sci. 20, 2: 117-22.

Koinaria, M, Karlb, S, Elliot, A, Ryana, U, Lymberyc, AJ, 2013: Identification of Anisakis species (Nematoda: Anisakidae) in marine fish hosts from Papua in New 
Guinea. Vet. Parasitol. 193:126-33.

Li Wen, X, Rui, S, Shan, G, Zou, WH, Nie P, et al, 2011: Seasonal occurrences of helminthes in the Anadromous Fish Coilia nasus (Engraulidae): parasite indicators of fish migratory movements. J. Parasitol. 97, 2:192-6.

Lymbery, AJ, Doupe, RG, Munshi, MA, Worg, T, 2002: Larvae of Contracaecum sp. among inshore species of south-western Australia. Oliseases Aqu. Organ. Dis Aguatorg 51: 157-9.

Mansour, MFA, Hassan, SH, Khidr, AA, Ghane, MA, 2003: General survey on certain helminthic parasites infecting some Nile fishes at El-Mansoura, Egypt. J. Aqua. Biol. Fish 7, 4:423-46.

Moravec, F, 1994: Parasitic Nematodes of Freshwater Fishes of Europe. Kluwer Academic Publishers Dordrecht, Netherland.

Muzzall, PM, Sweet, RD, Mijewski, CL, 1990: Occurrence of Diplostomum sp. (Tremaioda: Diplostomatidae) in pond-reared walleyes from Michigan. Progr. Fish-Cult. 52, 1:536.

Nada, MSM, Abd El-Ghany, AM, 2011: Anisakid nematodes in marine fishes. J. Amer. Sci. 7, 9:1000-5

Olurin, K, Okafor, J, Asiru, A, Ademiluwa, J, Owonifari, K, et al, 2012: Helminthes parasites of Sarotherodon galilaeus and Tilapia zillii (Pisces: Cichlidae) from River Oshun, Southwest Nigeria. Int. J. Aqua. Sci. 3, 2:4955.

Palm, HW, Klimpel, S, Walter, T, 2007: Demersal fish parasite fauna around the South Shetland Islands: high species richness and low host specificity in deep Antarctic waters. Polar Biol. 30:1513-22.

Quiazon, KM, Yoshinaga, T, Santos, M, Ogawa, K, 2009: Identification of larval Anisakis spp. (Nematoda: Anisaki dae) in Alaska Pollock (Theragra chalcogramma) in Northern Japan using morphological and molecular markers. J. Parasitol. 95, 5:23.

Rokicki, J, Rodjuk, G, Zdzitowiecki, K, Laskowski, Z, 2009: Larval ascaridoid nematodes (Anisakidae) in fish from the South Shetland Islands (Southern Ocean). Pol. Polar. Res. 30, 1:49-58.
Sabas, CS, Luque, J. L, 2003: Helminth parasites of Weakfish, Cynoscion guatucupa from coastal zone of the state of Rio de Janeiro, Brazil. Brazil J. Vet. Parasitol. 12, 4: 171-8.

Shamsi, S, Aghazadeh-Meshgi, M, 2011: Morphological and genetic characterization of selected Contracaecum (Nematoda: Anisakidae) larvae in Iran. Iranian J. Fisheries Sci. 10, 2:356-61.

Shamsi, S, Eisenbarth, A, Saptarshi, M, Ian, B, Robin, B, et al, 2010: Occurrence and abundance of anisakid nematode larvae in five species of fish from southern Australian waters. Parasitol. Res. 21, 1:34-9.

Shih, H,2004: Parasitic helminthes fauna of the cutlass fish, Trichiurus lepturus L., and the differentiation of four anisakid nematode thirdstage larvae by nuclear ribosomal DNA sequences. Parasitol. Res 93:188-95.

Sobecka, E, Szostakowska, B, MacKenzie, K, Hemmingsen, W, Prajsnar, S, et al, 2012: Genetic and morphological variation in Echinorhynchus gadi Zoega in (Muller, 1776) (Acanthocephala: Echinor- hynchidae) from Atlantic cod Gadusmor- hua L. J. Helminthol. 86:16-25.

Tantanasi, J, Daikon, A, Tamakis, L, Atjakas, B, 2012: Anisakis sp. burden in Trachurus trachurus. Helminthol. 49, 1:16-20.

Valero, A, López, M, Benítez, R, Adroher, FJ, 2006a: Anisakis spp. in European hake, Merluccius merluccius (L.) from the Atlantic off north-west Africa and the Mediterranean off southern Spain, Acta Parasitol. 51, 3:209.

Valero, A, Paniagua, MI, Hierro, IR, Diaz, V, Valderrama, MJ, et al, 2006b: Anisakid parasites of two fork beards (Phycisblennoides and Phycisphycis) from the Mediterranean coasts of Andaluc1'a (Sou-thern Spain). Parasitol. Int. 55:1-5.

Varjabedian, GK, 2005: Parasitic Nematodes of Freshwater Fish in Egypt. Publication of the National Biodiversity of Egypt.

Yakhchali, M, Tehrani, A, Ghoreishi, M, 2012: The occurrence of helminthes parasites in the gastrointestinal of catfish (Silurus glanis Linnaeus 1758) from the Zarrine-roud River, Iran. Vet. Res. Forum 3, 2:143-5. 